\title{
New Mexico Blue Grama Rangeland Response to Dairy Manure Application
}

\author{
Lanson J. Stavast, ${ }^{1}$ Terrell T. Baker, ${ }^{2}$ April L. Ulery, ${ }^{3}$ \\ Robert P. Flynn, ${ }^{4}$ M. Karl Wood, ${ }^{5}$ and Douglas S. Cram ${ }^{6}$

\begin{abstract}
Authors are ${ }^{1}$ Rangeland Management Specialist, USDA Forest Service, Spanish Forks, UT 84660;
${ }^{2}$ Extension Riparian Management Specialist, and ${ }^{6}$ Extension Research Specialist, Department of Extension Animal Resources, New Mexico State University, Las Cruces, NM 88003; ${ }^{3}$ Assistant Professor, Department of Agronomy and Horticulture, New Mexico State University, Las Cruces, NM 88003; ${ }^{4}$ Extension Agronomist, Artesia Agricultural Science Center, New Mexico State University, Artesia, NM 88210; and ${ }^{5}$ Director, New Mexico Water Resource Research Institute,
\end{abstract} Las Cruces, NM 88003.

\begin{abstract}
New Mexico supports over 290000 dairy cattle. These cattle produce large quantities of manure. It has been suggested excess dairy manure could be applied to rangelands as an organic fertilizer to increase soil fertility and herbaceous production. Manure was applied June 2000 to a rangeland in New Mexico dominated by blue grama (Bouteloua gracilis (Willd. ex Kunth) Lag. ex Griffiths) according to phosphorus (P) content: a recommended (light) rate $\left(54 \mathrm{~kg} \mathrm{P} \cdot \mathrm{ha}^{-1}\right)$ to enhance blue grama growth and a gross overapplication (heavy) rate $\left(493 \mathrm{~kg} \mathrm{P} \cdot \mathrm{ha}^{-1}\right)$ to determine their effects on vegetation. The actual application rate of manure on a dry weight basis was 0,11739 , and $107174 \mathrm{~kg} \cdot \mathrm{ha}^{-1}$. Four replications of control, light, and heavy rates were established. Herbaceous standing crop $\left(\mathrm{kg} \cdot \mathrm{ha}^{-1}\right)$ was similar 1 growing season after manure application, and greater 2 and 3 growing seasons after application on the light treatment compared with the control. Initially the heavy treatment suppressed herbaceous standing crop; thereafter, standing crop responded in a linear fashion to rainfall. Three growing seasons after manure application, basal cover was similar between light and control treatments, whereas the heavy treatment continued to be characterized principally by manure/litter cover. Heavy disposal-oriented treatments are not suitable for blue grama rangelands because of persistent declines in herbaceous cover and changes in soil salinity. A light manure application rate that is based on $\mathrm{P}$ content can increase forb and in particular grass standing crop on arid blue grama rangelands. Successful rangeland manure applications will depend on proper management to insure objectives are met while minimizing any hazards to the environment.
\end{abstract}

\section{Resumen}

Nuevo México sostiene cerca de 290000 vacas lecheras. Este ganado produce grandes cantidades de estiércol y se ha sugerido que el exceso de estiércol de ganado lechero pudiera ser aplicado en pastizales como fertilizante orgánico para incrementar la fertilidad del suelo y la producción de la vegetación herbácea. En Junio del 2000 se aplicó estiércol en pastizales de Nuevo Mexico dominados por el zacate "Blue grama" (Bouteloua gracilis (Willd. ex Kunth) Lag. ex Griffiths), con el objetivo de ver el impacto de la aplicación sobre la vegetación. De acuerdo al contenido de fósforo (P), las aplicaciones fueron: la cantidad recomendada (ligera) de $54 \mathrm{~kg} \mathrm{P} \cdot \mathrm{ha}^{-1}$ para mejorar el crecimiento del zacate "Blue grama" y una cantidad que representa una sobre aplicación (fuerte) de $493 \mathrm{~kg} \mathrm{P} \cdot \mathrm{ha}^{-1}$. La cantidad de estiércol aplicada en base a peso seco fue 0,11 739, y 107174 $\mathrm{kg} \cdot \mathrm{ha}^{-1}$. Se establecieron cuatro repeticiones del control, cantidad ligera, y cantidad fuerte. En la primera estación de crecimiento después de la aplicación de estiércol, la producción de biomasa en pie de la vegetación herbácea $\left(\mathrm{kg} \cdot \mathrm{ha}{ }^{-1}\right)$ fue similar entre tratamientos y en la segunda y tercera estaciones de crecimiento la producción de biomasa en la aplicación ligera fue superior que al tratamiento control. El tratamiento fuerte inicialmente redujo la producción de biomasa herbácea, pero posteriormente el pasto respondió de manera linear a la lluvia. Tres estaciones de crecimiento después de la aplicación del estiércol la cobertura basal fue similar entre el tratamiento ligero y el control, mientras que el tratamiento fuerte continuó caracterizándose principalmente por la cobertura de estiércol/mantillo. Los tratamientos orientados a la aplicación fuerte como medio de utilización del exceso de estiércol no son apropiados para pastizales de zacate "Blue grama" debido a la disminución persistente de la en cobertura herbácea y cambios en la salinidad del suelo. Una aplicación ligera de estiércol basada en P puede incrementar la producción de hierba y particularmente la biomasa de pasto en pastizales áridos de "Blue grama". Las aplicaciones exitosas de estiércol en pastizales dependerán de manejo apropiado para asegurar que los objetivos se cumplan mientras se minimiza cualquier riesgo para el medio ambiente.

Key Words: Bouteloua gracilis, rangeland application, snakeweed

Financial support was provided by New Mexico State University Agricultural Experimental Station and a USDA-CSRS Special Grant for Rangeland Ecosystem Research. At the time research was conducted, the senior author was a graduate research assistant, Animal and Range Sciences Department, New Mexico State University, Las Cruces, NM 88003. Correspondence: Terrell T. Baker, Dept of Extension Animal Resources, New Mexico State University, Las Cruces, NM 88003. Email: ttbaker@nmsu.edu 


\section{INTRODUCTION}

Producers of agricultural goods often create disposal/recycling challenges because of large amounts of generated by-products. Some by-products can be put to beneficial use. Dairies face a significant manure disposal challenge. Dairy cattle produce an estimated $86 \mathrm{~kg}$ of wet manure (feces and urine) $1000 \mathrm{~kg}$ animal $^{-1} \cdot \mathrm{d}^{-1}$ (American Society of Agricultural Engineers 1999). New Mexico has over 290000 dairy cattle (US Department of Agriculture-New Mexico Agricultural Statistical Service 2002). The New Mexico Environment Department requires dairies to dispose of manure quarterly each year. A portion is disposed through cropland application. Manure can only be applied to cropland before planting and after harvest because of crop damage risks during application. Disposal during the other 2 quarters of the year (growing season) is difficult and costly. Some dairies use sewage lagoons to hold the waste, haul it long distances, or stockpile it when it cannot be recycled locally.

Although dairies face manure recycling challenges, resource managers and ranchers face the problem of rangelands not meeting their full production potential. Most rangelands are being grazed to capacity but are below their production potential (Wood et al. 1986). Although rangelands can fall short of their production potential for many reasons, it is often because of poor quality and infertility of rangeland soils. Once areas become degraded, they continue to lose nutrients, water-holding capabilities, herbaceous cover, and soil particles through erosion. Numerous activities, including overgrazing, drought, and off-road vehicle use, have affected rangelands. Weed encroachment inhibits rangelands from reaching their full potential because of competition with more desirable species for water, nutrients, and space. Broom snakeweed (Gutierrezia sarothrae (Pursh) Britt. \& Rusby) is one example of a weed that is toxic to livestock and competes with desirable vegetation species.

New Mexico has about 28350000 ha of rangeland, a portion of which is adjacent to dairies located throughout the state. The dairies' manure disposal problem could present a means of increasing vegetation production to ranchers and resource managers. Manure generated by dairy cattle during the 2 quarters of the year when cropland disposal is difficult could be applied as organic fertilizer to nearby rangelands. Dwyer (1971) and Donart et al. (1978) found blue grama (Bouteloua gracilis (Willd. ex Kunth) Lag. ex Griffiths) rangeland treated with commercial fertilizer had significantly more production than untreated rangeland under both drought and favorable rainfall conditions. Manure application to rangelands has the potential to increase vegetation production and, possibly, rangeland carrying capacity. There could also be concomitant environmental benefits. Manure amendments to rangelands could contribute to the maintenance of, or increase in, soil fertility on these sites, thereby enhancing productivity. Obi and Ebo (1995) stated application of organic material to Nigeria's tropical soils is a necessity if degradation is to be reversed. Nigeria's soils are coarse and droughty (Obi and Ebo 1995). New Mexico also has coarse sandy soils, and because much of the state is arid, its rangelands also experience drought frequently. Many New Mexico soils lack nutrients because of low vegetation productivity, which further reduces organic matter addition to the soil.
Manure application to rangelands could be a long-term, rather than a short-term, investment. Obi and Ebo (1995) and Sweeten and Mathers (1985) stated improvements occur over a period $>2$ years. Degraded soils might not become immediately fertile, depending on their condition at the time of application, but it could slow degradation processes and, over time, enhance fertility and productivity. Potential problems associated with manure application include increased soil salinity and weed seed introduction.

Application of manure could alleviate dairy disposal problems and increase production on rangelands. Opportunities for providing other environmental benefits, such as decreasing erosion, improving wildlife and livestock forage and habitat, improving soil fertility, and sustainability, need to be explored. Objectives of this study were to determine manure application effects on vegetation production and composition and snakeweed populations.

\section{STUDY AREA}

This study was conducted in Sierra County, adjacent to the Black Range in western New Mexico (lat $33^{\circ} 28^{\prime} 23.7^{\prime \prime} \mathrm{N}$, long $107^{\circ} 42^{\prime}$ $\left.5.9^{\prime \prime} \mathrm{W}\right)$. Elevation is about $2190 \mathrm{~m}$. The mean annual precipitation is $305 \mathrm{~mm} \cdot \mathrm{y}^{-1}$ (Neher 1984) and comes mostly as rain in the late summer months (July-September). The frost-free period is about $140-180$ days, and the average daily temperature is $13^{\circ} \mathrm{C}$ (Neher 1984). The area contains many rolling hills, and the slope at our site is about $10 \%$. The predominant vegetation type is blue grama grassland near piñon pine-juniper (Pinus edulis Engelm.-Juniperus monosperma (Engelm) Sarg./J. deppeana Steud.) woodland. The soil is part of the Ildefonso soil series and is classified as a loamy-skeletal, mixed, mesic, Ustollic Calciorthid (Neher 1984). The Natural Resource Conservation Service described the soil as follows: moderately rapid permeability, low available water capacity, both wind and water erosion hazard are moderate, runoff potential is medium, and the available rooting depth is $152 \mathrm{~cm}$ or more (Neher 1984). The soil surface layer is a gravelly fine sandy loam formed from a mixed alluvium (Neher 1984). The soil textural class is sandy loam. In 1993, 12 plots $(25 \times 4 \mathrm{~m})$ were established $3 \mathrm{~m}$ apart and parallel to the slope of the terrain (Mosley 1996). Plots were framed with a metal border $15 \mathrm{~cm}$ high and $15 \mathrm{~cm}$ deep to keep precipitation and runoff within the plot area and to keep other runoff out of the plots. Fencing around the study site prevented livestock encroachment from surrounding grazing land.

\section{MATERIALS AND METHODS}

\section{Climate}

Weather data were collected on site with a CR-10x (Campbell Scientific, Logan, UT) data logger. Rainfall data was collected with a tipping bucket rain gauge (TE525). Data were collected hourly with totals recorded every 24 hours during the rainy season.

\section{Manure}

To calculate the manure application rates, stockpiled manure samples were randomly collected from a dairy near Las Cruces, 
New Mexico. Twenty samples were composited and analyzed by trace mineral analysis to determine total phosphorous $(\mathrm{P})$ content (Galyean and May 1995). The desired rate of $P$ was 0 , 45 , and $450 \mathrm{~kg} \mathrm{P} \cdot \mathrm{ha}^{-1}$; a control; a calculated amount of P to enhance blue grama productivity (light); and 10 times the recommended amount as a gross overapplication or a disposal application (heavy), respectively. Although application rates are often based on nitrogen $(\mathrm{N}), \mathrm{P}$ from manure application has become an environmental concern because of export $\mathrm{P}$ in watershed runoff, resulting in accelerated eutrophication in receiving fresh waters (Sharpley et al. 1999). Eutrophication, often as a result of $\mathrm{P}$ runoff, has been recognized as the main cause of impaired surface water quality (US Environmental Protection Agency 1996). Furthermore, because land application to rangelands not only supplies $\mathrm{N}$, a known benefit to blue grama, it was an underlying concern to look at $\mathrm{P}$ under New Mexico soil conditions (i.e., high $\mathrm{pH}$ ). Because specific $\mathrm{P}$ application rates for increasing blue grama production on rangelands were unavailable in the literature, we calculated a plausible application rate designed to yield a consistent increase in grass production. Calculations were based on estimated $\mathrm{P}$ removal on a healthy, rain-fed grassland with adequate N. Reasoning was as follows: analysis of blue grama tissue from southeastern New Mexico indicated it contained $0.22 \%$ P. Fertilized rangeland composed predominately of blue grama in south-central New Mexico achieved on average $1371 \mathrm{~kg} \cdot \mathrm{ha}^{-1}$ grass dry matter (Dwyer 1971). This equates to $3 \mathrm{~kg} \mathrm{P} \cdot \mathrm{ha}^{-1}$. Trace mineral analysis indicated application manure contained $0.46 \% \mathrm{P}$ on a dry weight basis. If manure at the recommended $\mathrm{P}$ application rate of $45 \mathrm{~kg} \mathrm{P} \cdot \mathrm{ha}^{-1}$ was added in a 1-time application, and presuming $80 \% \mathrm{P}$ availability (accounting for natural loss such as mineralization), $36 \mathrm{~kg} \mathrm{P} \cdot \mathrm{ha}^{-1}$ would be available for plant uptake. If annual average grass production yields $3 \mathrm{~kg} \mathrm{P} \cdot \mathrm{ha}^{-1}$ (as calculated from above), 12 years of $P$ would be added. This excess $P$ satisfied our application rate goal designed to yield a consistent increase in grass production and provided a framework from which to make a deduction on a plausible $\mathrm{P}$ application rate.

Manure was surface applied to plots by hand, 28-30 June 2000 according to calculations. During application, manure samples were collected randomly from each plot and later analyzed by trace mineral analysis (Galyean and May 1995) to determine the actual amount of $\mathrm{P}$ and $\mathrm{N}$ applied. Gravimetric moisture content $(61 \%)$ was measured to determine actual dry matter applied to plots. The average application rate for each treatment was (mean \pm SE) $0,54 \pm 2.8$, and $493 \pm 28.0 \mathrm{~kg}$ $\mathrm{P} \cdot \mathrm{ha}^{-1}$. The actual application rate of manure on a dry weight basis was 0,11739 , and $107174 \mathrm{~kg} \cdot \mathrm{ha}^{-1}$. After application, manure depth was $0.5-1 \mathrm{~cm}$ on the light treatment and 6-8 cm on the heavy treatment; except for a few woody shrubs, the manure on the heavy treatment completely blanketed the entire plot surface. Although we were unable to determine $\mathrm{N}$ content in the manure, analysis from 86 regional dairies showed manure $\mathrm{N}$ to range between $0.43 \%$ and $3.01 \%$, with a median of $1.71 \%$ (R. Flynn, personal communication, 2003).

\section{Soil}

Each of the study plots was systematically divided into 6 sections for sampling purposes. Within each of the 6 sections, a soil sample to a depth of $10 \mathrm{~cm}$ was randomly collected in each of the 12 plots. Manure was scraped off the area where soil was collected to prevent any cross contamination of soil samples. Samples were air dried to a constant weight then sieved to $\leq 2 \mathrm{~mm}$ effective diameter. Soils were tested by the saturated paste extract procedure (US Salinity Laboratory Staff 1954). Electrical conductivity of the saturated paste was measured 4 hours after the paste was mixed using an Accumet conductivity cell (Fisher Scientific, Pittsburgh, PA). Preapplication soil samples were collected in May 2000, whereas postapplication samples were taken at the end of the second growing season.

\section{Vegetation}

To estimate forage standing crop and species richness, vegetation was clipped and separated by species at the end of each growing season in 2000, 2001, and 2002. Ten randomly located frames $(305 \times 610 \mathrm{~mm})$ were clipped in each plot. Clippings were oven dried to a constant weight and weighed. Total vegetation dry matter was compared with data collected in 1999 (M.K. Wood, unpublished data, 1999). We counted all broom snakeweed plants in each plot at the end of each growing season (2000-2002) to determine the effects of manure application on broom snakeweed density. We compared these numbers to counts conducted in 1999. At the end of the 2002 growing season, blue grama inflorescences (hereafter, seedheads) were counted and heights were measured. Two randomly placed step-point (Evans and Love 1957) transects were used to select 20 blue grama plants within each plot. The closest blue grama plant to the step point was measured. Seedheads and heights were averaged for each plot and compared. Basal cover was determined by the line intercept method. In each plot, 2 randomly placed transects $22 \mathrm{~m}$ in length were used to determine the grass, forb, shrub, rock, bare ground, and litter cover (which included manure cover). Total length for each cover type was summarized by relative percentage.

\section{Analysis}

Statistical analyses were performed with SAS statistical software version 8.2 (SAS Institute, Cary, NC). All variables were checked for normality with PROC UNIVARIATE (SAS Institute 1999). Those variables that were not normally distributed were analyzed with PROC NPAR1WAY (SAS Institute 1999) and the Kruskal-Wallis test. Analysis of variance was used to determine significant differences between treatments within years. Repeated measures analysis was conducted with PROC MIXED (SAS Institute 1999) on variables collected for 3 growing seasons. Duncan's new multiple range test was used to separate the means at $\alpha=0.05$ after significance had been determined. Species richness was calculated by year per treatment at the subplot $\left(1.9 \mathrm{~m}^{2}\right)$ level.

\section{RESULTS AND DISCUSSION}

\section{Climate}

Rainy season (July-September) precipitation values for the years 1999-2002 were 331, 207, 308, and $121 \mathrm{~mm}$, 
Table 1. Mean (SE) herbaceous standing crop on a blue grama rangeland in Sierra County, New Mexico, treated (June 2000) with dairy manure. Light manure application rate was the recommended $P$ (54 kg P.ha $\left.{ }^{-1}\right)$; the heavy rate was overapplication of $P(493 \mathrm{~kg}$ $\left.\mathrm{P} \cdot \mathrm{ha}^{-1}\right){ }^{1}$

\begin{tabular}{ccccc}
\hline & & Forb & Grass & Total \\
\cline { 3 - 5 } Year & Treatment & \multicolumn{3}{c}{$\left(\mathrm{kg} \cdot \mathrm{ha}^{-1}\right)$} \\
\hline 1999 & Control & $313^{\mathrm{a}}(79)$ & $1210^{\mathrm{a}}(113)$ & $1518^{\mathrm{a}}(112)$ \\
& Light & $242^{\mathrm{a}}(63)$ & $1146^{\mathrm{a}}(95)$ & $1384^{\mathrm{a}}(69)$ \\
& Heavy & $257^{\mathrm{a}}(37)$ & $1172^{\mathrm{a}}(40)$ & $1424^{\mathrm{a}}(68)$ \\
2000 & Control & $276^{\mathrm{a}}(62)$ & $1124^{\mathrm{a}}(175)$ & $1401^{\mathrm{a}}(143)$ \\
& Light & $354^{\mathrm{a}}(91)$ & $1018^{\mathrm{a}}(124)$ & $1372^{\mathrm{a}}(37)$ \\
& Heavy & $192^{\mathrm{a}}(51)$ & $494^{\mathrm{b}}(98)$ & $687^{\mathrm{b}}(123)$ \\
2001 & Control & $303^{\mathrm{a}}(57)$ & $1399^{\mathrm{a}}(217)$ & $1702^{\mathrm{a}}(244)$ \\
& Light & $303^{\mathrm{a}}(97)$ & $1907^{\mathrm{a}}(162)$ & $2210^{\mathrm{a}}(164)$ \\
\multirow{2}{*}{2002} & Heavy & $1017^{\mathrm{b}}(79)$ & $1976^{\mathrm{a}}(261)$ & $2994^{\mathrm{b}}(259)$ \\
& Control & $68^{\mathrm{a}}(30)$ & $673^{\mathrm{a}}(60)$ & $742^{\mathrm{a}}(51)$ \\
& Light & $92^{\mathrm{a}}(26)$ & $1098^{\mathrm{b}}(104)$ & $1191^{\mathrm{b}}(103)$ \\
& Heavy & $124^{\mathrm{a}}(67)$ & $670^{\mathrm{a}}(40)$ & $795^{\mathrm{a}}(27)$ \\
\hline
\end{tabular}

${ }^{1}$ Duncan's new multiple range test was used to separate the means at $\alpha=0.05$. Means in the same column within the same year followed by the same letter are not significantly different.

respectively. The 30-year (1971-2000) average rainy season precipitation for this region is $212 \mathrm{~mm}$ (US Department of Agriculture-Natural Resources Conservation Service 2003). In addition to the lack of rain in 2002 during the rainy season, the 6 preceding months were also dry, receiving only $16 \mathrm{~mm}$ of precipitation. The recorded amount of precipitation is at or below the low end of what Martin and Berry (1970) recommended $\left(300-800 \mathrm{~mm} \cdot \mathrm{y}^{-1}\right)$ for application of $\mathrm{N}$ fertilizers on rangelands to be considered beneficial.

\section{Vegetation}

Pretreatment (1999) grass standing crop $\left(\mathrm{kg} \cdot \mathrm{ha}^{-1}\right)$ was not significantly different among treatment sites (Table 1). One growing season (2000) following manure application grass

\section{四 shrub $\square$ forb $\mathbf{0}$ grass $\square$ litter $\mathbf{m}$ rock $\mathbb{\mathbb { Q }}$ bare}

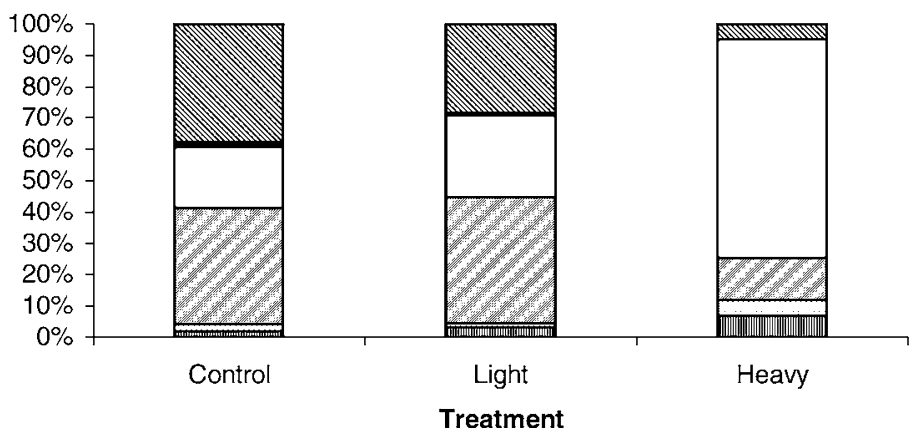

Figure 1. Percent cover (2002) on a New Mexico blue grama rangeland in Sierra County treated with a 1-time application of dairy manure (June

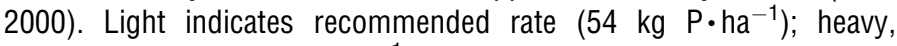
overapplication (493 $\mathrm{kg} \mathrm{P} \cdot \mathrm{ha}^{-1}$ ). Litter includes manure cover.
Table 2. Mean (SE) blue grama inflorescences (seedheads) and heights at the end of the third growing season (September 2002) after application of dairy manure (June 2000) on a blue grama rangeland in Sierra County, New Mexico. Light manure application rate was the recommended $\mathrm{P}\left(54 \mathrm{~kg} \mathrm{P} \cdot \mathrm{ha}^{-1}\right)$; the heavy rate was overapplication of $\mathrm{P}\left(493 \mathrm{~kg} \mathrm{P} \cdot \mathrm{ha}^{-1}\right)$. $^{1}$

\begin{tabular}{cccc}
\hline Year & Treatment & $\begin{array}{c}\text { Inflorescence } \\
\text { Density } \\
\left.\text { (seedheads } \cdot \text { caspitose }^{-1}\right)\end{array}$ & $\begin{array}{c}\text { Inflorescence } \\
\text { Height } \\
(\mathrm{cm})\end{array}$ \\
\hline 2002 & Control & $54^{\mathrm{a}}(19)$ & $10^{\mathrm{a}}(0.3)$ \\
& Light & $214^{\mathrm{b}}(21)$ & $13^{\mathrm{b}}(0.6)$ \\
& Heavy & $403^{\mathrm{c}}(93)$ & $18^{\mathrm{c}}(1.2)$ \\
\hline
\end{tabular}

${ }^{1}$ Duncan's new multiple range test was used to separate the means at $\alpha=0.05$. Means in the same column followed by the same letter are not significantly different.

standing crop on the control and light treatments was comparable, but significantly greater compared with the heavy treatment (Table 1). We speculated this initial decrease in grass standing crop on the heavy treatment was caused by the suppressive nature of the manure's weight $\left(107174 \mathrm{~kg} \cdot \mathrm{ha}^{-1}\right)$ and depth $(6-8 \mathrm{~cm}$ deep across the entire treatment.) Two growing seasons (2001) after application, grass standing crop across all treatments was not different (Table 1). In 2002, 3 growing seasons after manure application, grass standing crop was reduced by about one-half across all treatments, but the light treatment had the greatest standing crop (about $427 \mathrm{~kg} \cdot \mathrm{ha}^{-1}$ greater than the control and heavy treatments) and remained above $1000 \mathrm{~kg} \cdot \mathrm{ha}^{-1}$. The severe drought conditions in 2002 are the most probable cause for this decline in grass standing crop.

Three growing seasons after manure application, the greatest basal cover type was grass on the light $(40 \%)$ and control $(37 \%)$ treatments, whereas litter/manure $(70 \%)$ remained the greatest cover type on the heavy treatment (Fig. 1). Although the heavy treatment exhibited greater litter/manure cover and less herbaceous cover after 3 growing seasons, paradoxically, mean blue grama seedheads and heights were denser and taller, respectively, compared with the other 2 treatments (Table 2). This increase in seedhead height and density, as seen in both the

Table 3. Mean (SE) electrical conductivity (dS $\cdot \mathrm{m}^{-1}$ ) comparisons before (May 2000) and after (September 2001) manure application on a blue grama rangeland in Sierra County, New Mexico. Light manure application rate was the recommended $\mathrm{P}\left(54 \mathrm{~kg} \mathrm{P} \cdot \mathrm{ha}^{-1}\right)$; the heavy rate was overapplication of $\mathrm{P}\left(493 \mathrm{~kg} \mathrm{P} \cdot \mathrm{ha}^{-1}\right){ }^{1}$

\begin{tabular}{lcc}
\hline Year & Treatment & $\begin{array}{c}\text { Electrical Conductivity } \\
\left(\mathrm{dS} \cdot \mathrm{m}^{-1}\right)\end{array}$ \\
\hline 2000 & Control & $0.32^{\mathrm{a}}(0.01)$ \\
& Light & $0.32^{\mathrm{a}}(0.01)$ \\
& Heavy & $0.33^{\mathrm{a}}(0.01)$ \\
2001 & Control & $0.23^{\mathrm{a}}(0.01)$ \\
& Light & $0.97^{\mathrm{a}}(0.03)$ \\
& Heavy & $7.76^{\mathrm{b}}(0.58)$ \\
\hline
\end{tabular}

${ }^{1}$ Duncan's new multiple range test was used to separate the means at $\alpha=0.05$. Means in the same column within the same year followed by the same letter are not significantly different. 

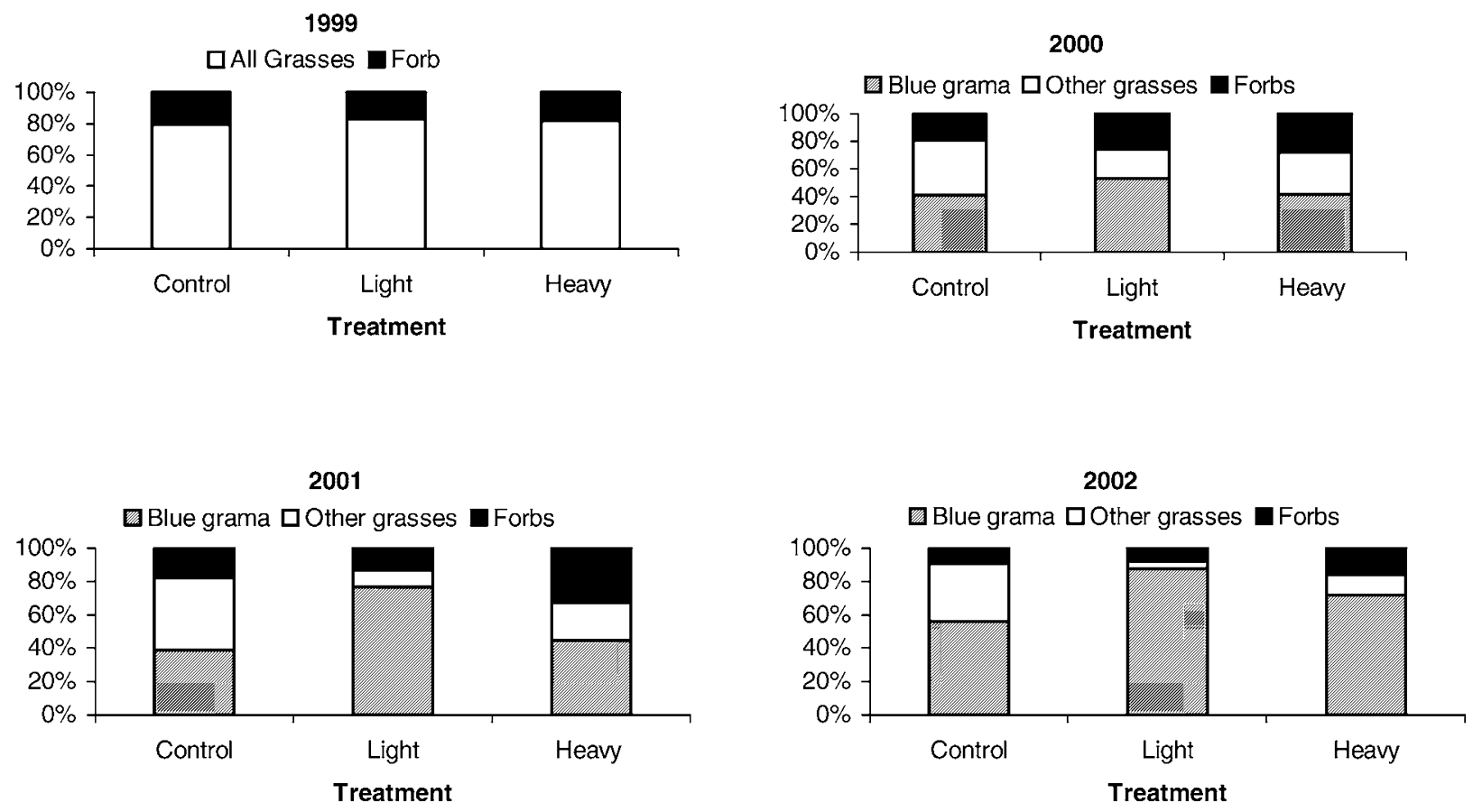

Figure 2. Percent standing crop of blue grama, other grasses, and forbs on a New Mexico blue grama rangeland in Sierra County following a 1-time application of dairy manure (June 2002). No distinction was made between species in 1999. Percentages are based on production weight. Light indicates recommended rate $\left(54 \mathrm{~kg} \mathrm{P} \cdot \mathrm{ha}^{-1}\right)$; heavy, overapplication $\left(493 \mathrm{~kg} \mathrm{P} \cdot \mathrm{ha}^{-1}\right)$.

light and heavy treatments, can be attributed to the increase of nutrients available to the blue grama plants, increased waterholding capacity of the manure treated soil, and temperature effects caused by the manure.

Forb standing crop $\left(\mathrm{kg} \cdot \mathrm{ha}^{-1}\right)$ was not significantly different among treatment sites before manure application or 1 growing season after application (Table 1). However, 2 growing seasons after manure application, forb standing crop on the heavy treatment increased 5 -fold over the previous year. The increase in forb standing crop on the heavy treatment in 2001 was mainly due to an increase in Watson's goosefoot (Chenopodium watsonii A. Nels.). We believe Watson's goosefoot seed was introduced with the manure. Furthermore, this increase could be related to changes in soil salinity. After manure application, soil beneath the heavy treatment became saline (electrical conductivity $>4 \mathrm{dS} \cdot \mathrm{m}^{-1}$; Table 3 ). Watson's goosefoot is a member of the Chenopodiaceae family, which is known for its salt tolerance. Three growing seasons after manure treatment, forb standing crop was greatly reduced across all treatments. Similar to grass standing crop 3 growing seasons after application, drought effects, particularly during the early growing season (April, May, June) is a probable cause for the decrease in forb standing crop. Total herbaceous (grasses and forbs) standing crop on light treatments was consistent with the findings of McKell et al. (1970), White et al. (1997), Benton and Wester (1998), and Pierce et al. (1998). Species composition by weight shifted as a result of manure application (Fig. 2). On the light and heavy treatments, percent blue grama by weight continued to increase through the 3 growing seasons after manure application.

Forty-one herbaceous species from 22 different families were encountered within the study plots. The most dominant species every year of the study was blue grama. Mean species richness was not significantly different among treatments in 2000 or 2001 (Fig. 3). However, in 2002, species richness in the light (7) and heavy treatments (6) was significantly lower than the control (13). Species richness might have decreased in the light and heavy treatments because the plot became increasingly dominated by blue grama (Fig. 2). Furthermore, the decrease in species richness in the heavy treatment might be a result

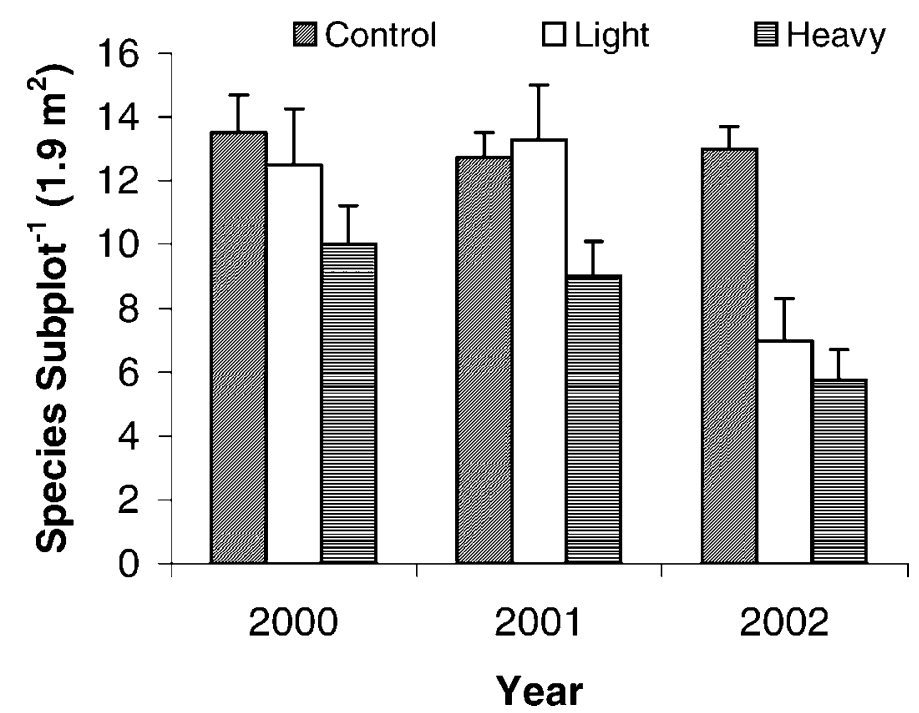

Figure 3. Mean species richness following application of dairy manure to a blue grama rangeland in Sierra County, New Mexico. Light indicates recommended rate $\left(54 \mathrm{~kg} \mathrm{P} \cdot \mathrm{ha}^{-1}\right)$; heavy, overapplication (493 kg $\left.P \cdot h a^{-1}\right)$. Bars with each mean are SEs. 


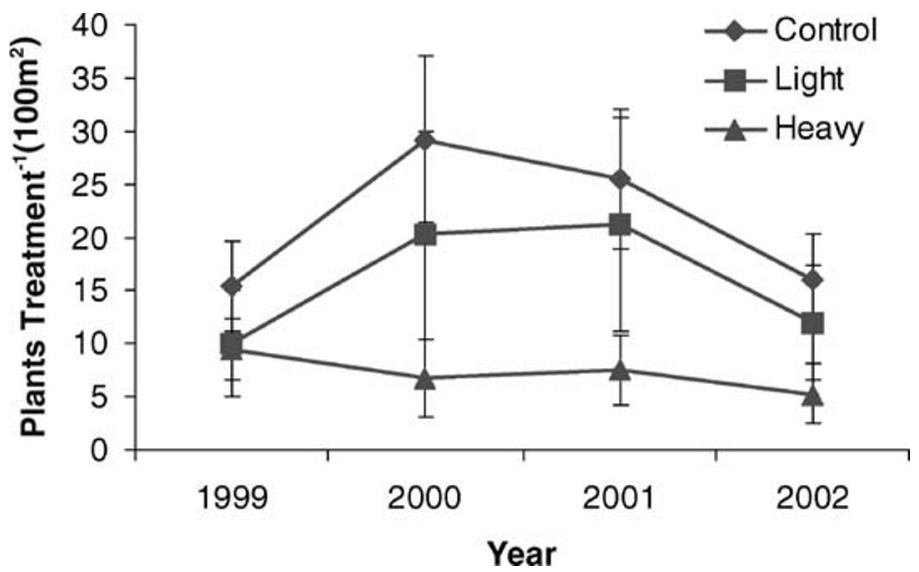

Figure 4. Snakeweed density on a blue grama rangeland in Sierra County, New Mexico, treated (2000) with dairy manure. Light indicates recommended rate $\left(54 \mathrm{~kg} \mathrm{P} \cdot \mathrm{ha}^{-1}\right.$ ); heavy, overapplication (493 kg $\left.\mathrm{P} \cdot \mathrm{ha}^{-1}\right)$. Bars with each mean are SEs.

of the persistence of litter/manure cover 3 growing seasons after application and the increase in soil salinity favoring Chenopodium.

Broom snakeweed densities in the heavy treatment were lower in all years when compared with the control, but differences were not significant because of the high variation among plots within the light treatment (Fig. 4). This pattern of suppression was similar to the findings of Fresquez et al. (1990), who found a significant decrease in broom snakeweed numbers on plots receiving heavy applications of sewage sludge compared with untreated plots.

\section{CONCLUSIONS AND MANAGEMENT IMPLICATIONS}

The light manure treatment at the recommended rate of $54 \mathrm{~kg}$ $\mathrm{P} \cdot \mathrm{ha}^{-1}$ increased herbaceous standing crop and cover. Depending on management objectives, this could be of particular interest during years with inconsistent precipitation. Relative to blue grama in control treatments, robust blue grama growth characteristics, such as greater inflorescence height and density, in the light treatment might also benefit producers in terms of increased herbaceous standing crop and cover. The heavy treatment of $493 \mathrm{~kg} \mathrm{P} \cdot \mathrm{ha}^{-1}$ (the gross overapplication or disposal rate) resulted in a pendulum-like reaction, a suppression of the herbaceous standing crop the first growing season, a "boom" year after the second growing season, and a "bust" year the third growing season after application. This closely followed precipitation accumulations. Heavy disposal-oriented treatments are not suitable for blue grama rangelands because of persistent declines in herbaceous cover and changes in soil salinity. Although broom snakeweed densities were initially suppressed, heavy manure applications should not be considered a solution for reducing snakeweed cover. The increased soil salinity in conjunction with the possible introduction of Watson's goosefoot calls for further research. The effect of repeated light applications remains to be answered. Monitoring of percent herbaceous cover and species richness should continue in order to determine the long-term effects of light and heavy manure application on blue grama rangelands.
As rangeland manure applications continue to receive more attention, guidelines for application will be useful to managers and producers. Rangeland benefits, such as increased standing crop and vegetative basal cover and soil amelioration, will need to be balanced with concerns such as nutrient accumulations and surface and groundwater quality. Proper management will be the key to ensuring that objectives are met while minimizing any hazards to the environment.

\section{ACKNOWLEDGMENTS}

The authors thank C. Stavast, C. Wood, B. Mertz, B. Allred, K. Tshireletso, A. Lujan, and T. Milton for assistance in the field; Bright Star Dairy for their manure; Dr R. Steiner for assistance with statistical analyses; the US Forest Service for use of the study plots; and 2 anonymous reviewers for helpful comments on an earlier draft.

\section{LITERATURE CITED}

[ASAE] American Society of Agricultural Engineers. 1999. Manure production and characteristics. In: ASAE standards. St Joseph, MI: ASAE. p 663-665.

Benton, M. W., AND D. B. Wester. 1998. Biosolids effects on tobosagrass and alkali sacaton in a Chihuahuan desert grassland. Journal of Environmental Quality 27:199-208.

Donart G. B., E. E. Parker, R. D. Pieper, and J. D. Wallace. 1978. Nitrogen fertilization and livestock grazing on blue grama rangeland. In: D. N. Hyder [ed.]. Proceedings of the 1st International Rangeland Congress; 14-18 August 1978; Denver, CO. Denver, C0: Society for Range Management. p 614-615.

DWYER, D. D. 1971. Nitrogen fertilization on blue grama range in the foothills of south-central New Mexico. Las Cruces, NM: New Mexico State University Agricultural Experiment Station Bulletin 585. 8 p.

Evans, R. A., And R. M. Love. 1957. The step-point method of samplinga practical tool in range research. Journal of Range Management 10:208-213.

Fresquez, P. R., R. E. Francis, and G. J. Dennis. 1990. Soil and vegetation responses to sewage sludge on a degraded semiarid broom snakeweed/blue grama plant community. Journal of Range Management 43:325-331.

Galyean, M., AND T. May. 1995. Laboratory procedures in animal nutrition research. Las Cruces, NM: Department of Animal and Range Sciences, New Mexico State University. $10 \mathrm{p}$.

Martin, W. E., and L. J. BerRy. 1970. Use of nitrogenous fertilizers on California rangeland. In: M. J. T. Norman [ed.]. Proceedings of the 11th International Grassland Congress; 13-23 April 1970; Surfers Paradise, Queensland, Australia. St. Lucia, Queensland, Australia: University of Queensland Press. p 817-822.

McKell, C. M., V. W. Brown, R. H. Adolph, and C. Duncan. 1970. Fertilization of annual rangeland with chicken manure. Journal of Range Management 23 : $336-340$.

MosLey, J. H. 1996. Runoff and erosion following snakeweed control [thesis]. Las Cruces, NM: New Mexico State University. $58 \mathrm{p}$.

Neher, R. E. 1984. Soil survey of Sierra County area, New Mexico. Washington, DC: US Department of Agriculture, Soil Conservation Service. 80 p.

OBI, M. E., AND P. O. EBo. 1995. The effects of organic and inorganic amendments on soil physical properties and maize production in a severely degraded sandy soil in southern Nigeria. Bioscience Technology 51:117-123.

Pierce, B. L., E. F. Redente, K. A. Barbarick, R. B. Brobst, and P. Hegeman. 1998. Plant biomass and elemental changes in shrubland forages following biosolid application. Journal of Environmental Quality 27:789-794.

SAS InstituTE. 1999. SAS/STAT user's guide: version 8. Cary, NC: SAS Institute. Sharpley, A. N., T. Daniel, T. Sims, J. Lemunyon, R. Stevens, and R. Parry. 1999. Agricultural phosphorus and eutrophication. University Park, PA: US Department of Agriculture, Agricultural Research Service ARS-149. 42 p.

SweEten, J. M., and A. C. Mathers. 1985. Improving soils with livestock manure. Journal of Soil and Water Conservation 40:206-210. 
US Department of Agriculture-Natural Resources Conservation Service. 2003. New Mexico climate information. Available at: http://www.nm.nrcs.usda.gov/snow/ climate/. Accessed 8 January 2003.

US Department of Agriculture-New Mexico Agricultural Statistical Service. 2002. Census of Agriculture-January, New Mexico cattle, sheep, and goat survey. Available at: http://www.nass.usda.gov/census/. Accessed 8 January 2003.

US Environmental Protection Agency. 1996. Environmental indicators of water quality in the United States. EPA 841-R-96-002. $30 \mathrm{p}$.
US Salinity LaboRatory StafF. 1954. Diagnosis and improvement of saline and alkaline soils. Agriculture Handbook 60. Washington, DC: US Department of Agriculture, US Government Printing Office.

White, C. S., S. R. Loftin, and R. Aguilar. 1997. Application of biosolids to degraded semiarid rangeland: nine year responses. Journal of Environmental Quality 26:1663-1671.

Wood, M. K., G. B. Donart, and M. Weltz. 1986. Comparative infiltration rates and sediment production on fertilized and grazed blue grama rangeland. Journal of Rangeland Management 39:371-374. 